\title{
Can Digital Inclusive Finance Narrow the Chinese Urban-Rural Income Gap? The Perspective of the Regional Urban-Rural Income Structure
}

\author{
Naishu Yu* and Yanzhe Wang \\ School of Economics, Jilin University, Changchun 130012, China; xiahou163@163.com \\ * Correspondence: yns@jlu.edu.cn
}

check for

updates

Citation: Yu, N.; Wang, Y. Can Digital Inclusive Finance Narrow the Chinese Urban-Rural Income Gap? The Perspective of the Regional Urban-Rural Income Structure. Sustainability 2021, 13, 6427. https:/ / doi.org/10.3390/su13116427

Received: 29 April 2021

Accepted: 1 June 2021

Published: 4 June 2021

Publisher's Note: MDPI stays neutral with regard to jurisdictional claims in published maps and institutional affiliations.

Copyright: (c) 2021 by the authors. Licensee MDPI, Basel, Switzerland. This article is an open access article distributed under the terms and conditions of the Creative Commons Attribution (CC BY) license (https:/ / creativecommons.org/licenses/by/ $4.0 /)$.

\begin{abstract}
This paper empirically studies the impact of digital inclusive finance on the income structure of urban and rural residents in eastern, central, and western China. The results show that, first, digital inclusive finance is beneficial to narrowing the urban-rural per capita disposable income gap that has a disequilibrium effect among regions. Second, narrowing the wage income, property income, and transfer income gaps is beneficial but has little effect on the net operating income gap between urban and rural residents. Third, narrowing the wage income, property income, and transfer income gaps reduces the total income gap, and the wage income gap has the strongest intermediary force. In the end, the paper puts forward corresponding countermeasures for the development of digital inclusive finance to narrow each of these income gaps in different regions of China.
\end{abstract}

Keywords: digital inclusive finance; income gap between urban and rural areas; structure of urban and rural income; mediating effect model

\section{Introduction}

Recently, Chinese people's living standards have improved, and total income has grown steadily. For instance, per capita disposable income has increased from 66 yuan at the time of the founding of the People's Republic of China to 28,228 yuan in 2019. However, the urban-rural income gap has always existed because of the unique urban-rural dual economic structure in China. Although it has narrowed under the efforts of various aspects since the economy entered the new normal, the urban-rural income gap measured by the ratio of urban and rural per capita disposable income still hovers between 2.44 and 2.51 times. The income gap between urban and rural areas prevents rural residents from enjoying the dividends of rapid economic development, which is detrimental to social stability and fair governance.

In this context, inclusive finance is an important link in promoting Chinese financial supply-side structural reform that constantly expands the coverage of finance on the principle of opportunity equality and commercial sustainability and enables the financial supplier to simultaneously obtain considerable income through risk control and pricing optimization. The digital financial pattern has gradually emerged through the deep integration of digital technologies, such as mobile Internet, big data, artificial intelligence, and traditional financial services. Information technology and product innovation have expanded the coverage of financial services, reduced the cost of financial services, and improved the ability to reach clients. As a result, digital inclusive finance - an upgraded version of inclusive finance enabled by digital finance, has appeared. Through digital finance, this emerging form attempts to realize the essential requirements of inclusive finance: solving the problem of the cost-benefit inversion of traditional inclusive finance and alleviating the plight of financial exclusion to increase disadvantaged groups' income and reduce the income gap between urban and rural residents.

In addition to practical exploration, many scholars have carried out extensive research on this topic. Foreign researchers have focused on the relationship between finance or 
inclusive finance and the urban-rural income gap, but have seldom mentioned digital inclusive finance. In the earlier years, Waller found that the lack of finance led to a widening of the income gap through financing constraints [1]. In view of this problem, Chakravarty used data from India to verify that the development of inclusive finance can narrow the urban-rural income gap [2]. Anand and Chhikara demonstrated that the level of inclusive finance promoted the balanced development between urban and rural areas [3]. Schmied and Marr studied Peru and found that financial inclusion significantly affects poverty reduction [4]. Thus, the income gap between urban and rural residents is narrowing through the development of finance - especially inclusive finance.

In contrast, digital inclusive finance was first applied and implemented in China, and some scholars have researched its function. For example, Song first proposed the judgment that digital inclusive finance helped narrow the urban-rural income gap by using provincial panel data from China [5]. Zhang and Tan also reached the same conclusion using a spatial panel econometric model and further believed that the coverage of digital inclusive finance had a stronger effect on reducing the per capita disposable income gap between urban and rural residents [6]. On this basis, Zhang and Bai analyzed in depth the convergence mechanism of digital inclusive finance on urban and rural income [7]. Liang and Liu put forward the threshold effect, poverty reduction effect, and exclusion effect in the practice of digital inclusive finance according to observations of financial deepening theory [8]. Xiong and Chen evaluated the disequilibrium effect and threshold effect of digital inclusive finance on the income gap and put forward the policy suggestion that the economic development of urban and rural areas should be coordinated [9].

At present, many scholars are exploring the influencing factors or effects of income gap. As for total income gaps, Ciani has studied the role of income inequality in the importing country as a determinant of export unit value and product quality estimated employing information on market shares and prices [10]. Kotschy and Sundeshow show how income inequality plays a crucial role in the effects of economic shocks on democracy [11]. Yu and $\mathrm{Li}$ evaluated the effect of social security expenditure in reducing income inequality and rural poverty with cointegration analysis [12]. Furusawa finds that the winner-take-all trend of product markets causes a war for talent, which exacerbates income inequality within the countries and leads to labor-market polarization [13]. Foltz analyzed the role that Chinese lineage networks can play in alleviating income inequality in rural villages through their effect on migration from rural to urban areas [14]. Thiede studied patterns of inequality at subnational scales and how they vary between and within rural and urban localities [15]. Additionally, in terms of income structure, Wen and Li used the Gini coefficient and its decomposition method to calculate the contribution rates of different income sources to the urban-rural income gap in Inner Mongolia [16]. Xiao and Zhong used provincial panel data to empirically test the impact of different types of basic public services from different sources on the income gap between urban and rural residents [17]. However, they did not consider factors related to digital inclusive finance.

The literature review shows that almost all existing studies related to the urban-rural income gap only examined the narrowing impact of digital inclusive finance from the perspective of overall disposable income. However, does digital inclusive finance have the same effect on each component of the income structure? How does the income gap of different sub-items affect the total income gap between urban and rural residents? Understanding these issues will help to further consider the influence mechanism of digital inclusive finance on the urban-rural income gap to draw more targeted policy suggestions. Therefore, this paper studies the impact of digital inclusive finance on the overall income gap and the income structure gap between urban and rural residents.

The remainder of the paper is scheduled as follows. First, after the literature review, this paper puts forward six research hypotheses and the corresponding theoretical framework about the narrowing effect of digital inclusive finance on the income gap. Second, this paper uses the provincial panel data from 2014 to 2018 to empirically test the above 
hypothesis with the panel data model. Third, this paper analyzes the results and puts forward corresponding suggestions for the income gap of each sub-item.

\section{Materials and Methods}

\subsection{Theoretical Framework and Research Hypothesis}

Digital inclusive finance is an upgraded version of traditional inclusive finance enabled by digital technology and significantly affects the income of both urban and rural residents. The middle- and low-income groups are the main beneficiaries in urban areas and generally lack "hard information," such as high-quality assets, but can obtain personalized loan plans through "soft information," such as credit records. In daily life, Internet payments based on third-party credit provide middle- and low-income groups with comprehensive financial services, which makes it possible for them to obtain financial income from idle funds. The asset portfolio advice given by intelligent investment consultants also helps improve the investment income of such people.

Compared with the urban benefit groups, the scope of benefits in rural areas is more extensive. Scenario-type lending services and crowdfunding platforms supplemented by niche insurance types in the insurance market alleviate financing constraints and effectively avoid operational risks. In daily life, the Internet payment breaks through the boundary of time and space, improves consumption efficiency, and significantly increases farmers' wage income by driving production and promoting enterprises' revenues. Low threshold financial products make up for deficiencies in traditional fund investments and increase farmers' financial income.

In conclusion, because digital inclusive finance has different effects on urban and rural residents' income, it should also significantly affect the urban-rural income gap. Next, from the perspective of total income and the income structure, this paper considers regional characteristics and further discusses the impact of digital inclusive finance on the income gap. Figure 1 provides a diagram of the theoretical mechanism.

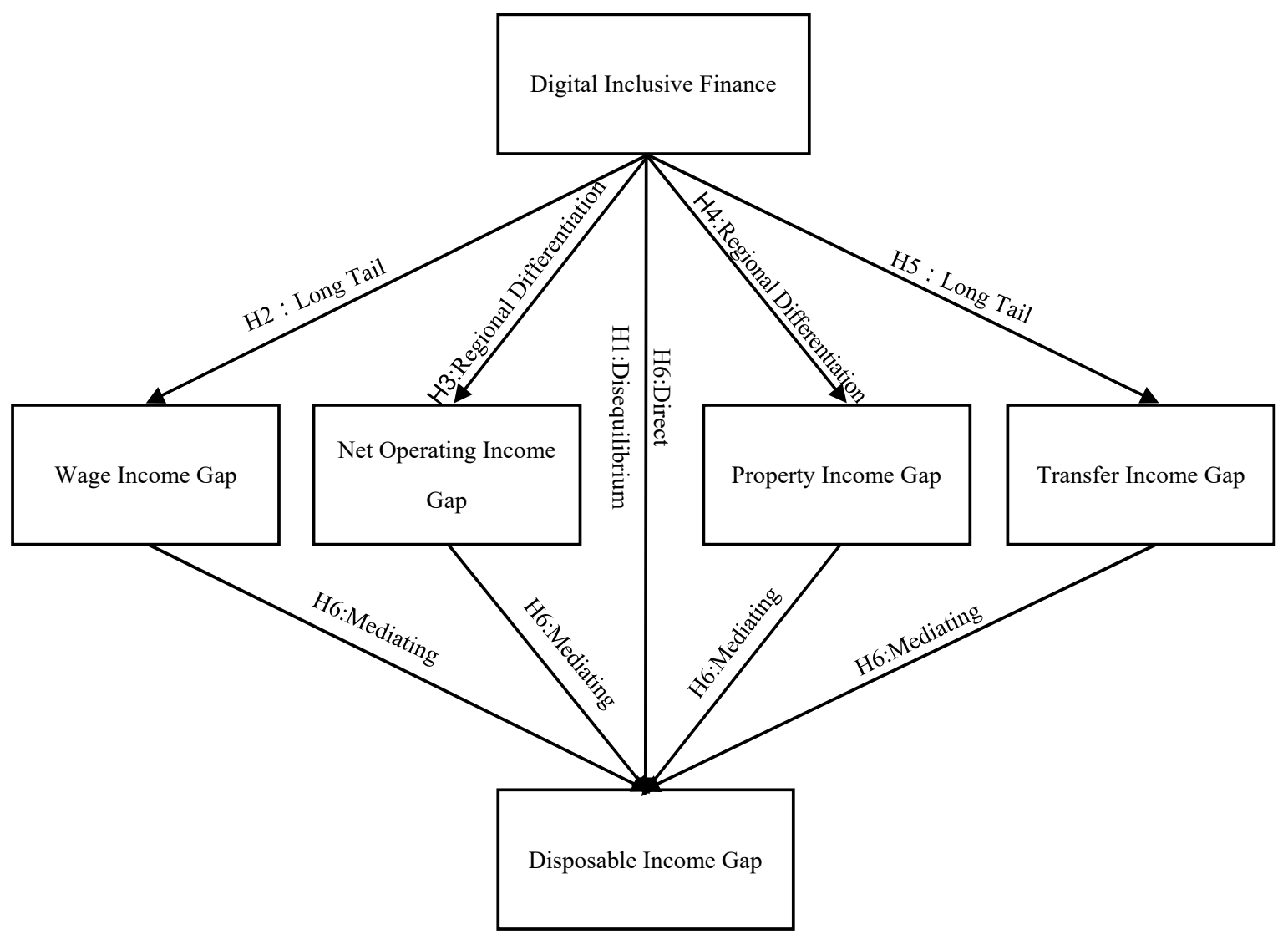

Figure 1. Theoretical Mechanism Diagram. 
Given a digital inclusive finance background, groups in urban areas that benefit are mainly middle- and low-income groups, whereas the benefitting groups in rural areas are comprised of almost all households, enabling digital inclusive finance to play a role in benefiting the poor. From this point of view, digital inclusive finance more strongly promotes increases in the supply of rural financial services, which accurately matches farmers' continuous high demand and helps narrow the income gap between urban and rural residents. However, the development among different regions of China is not balanced. The development of digital inclusive finance is expected to have regional differences [9] and, thus, different effects on narrowing the income gap because of the different effects of government policies and the construction of digital facilities. Therefore, Hypothesis 1 is proposed as follows.

Hypothesis 1. Digital inclusive finance is conducive to narrowing the income gap between urban and rural residents, and a disequilibrium effect exists among regions.

However, the impact of digital inclusive finance on the urban-rural income gap cannot be generalized but needs to be analyzed in combination with the income structure. Wage income mainly refers to labor payments. Digital inclusive finance solved the financing problems of small and micro enterprises in rural areas, made it popular to return home to start businesses, and provided more employment opportunities for non-agricultural groups [18-21]. Therefore, digital inclusive finance is conducive to narrowing the wage income gap between urban and rural areas. In terms of regional differences, digital inclusive finance can play a better role in western China, which has poorly developed regional banks and capital markets [22]. The reason is that financial supervision in the western backward regions with a low entry threshold of policies is not yet perfect, enabling digital inclusive finance to easily enter the market. This situation implies that, compared with in the eastern region, small and micro enterprises in the western region are more likely to break financing constraints, thus increasing the number of jobs in the region, increasing wage income, and alleviating the wage income gap. Therefore, Hypothesis 2 is proposed as follows:

Hypothesis 2. Digital inclusive finance is conducive to narrowing the wage income gap between urban and rural residents, and a long tail effect exists among regions.

Net operating income refers to the net income of household members engaged in production and business activities. Because most urban residents have decent jobs, whereas rural residents lack employment income and often rely on land to obtain income, rural residents' income is generally higher than that of urban residents. Therefore, the change in this source of income more strongly affects rural residents. By relying on digital technology, digital inclusive finance drives the development of the trading platform of the digital industry chain. Leading enterprises are more likely to release order information and accept the platform's feedback. Farmers and poor enterprises are also more likely to search for order information, produce according to demand, and increase operating income, thus widening the gap between urban and rural residents. In terms of regional differences, the eastern and central rural areas with a higher degree of development are more likely to introduce agricultural insurance to reduce operational risks. Additionally, more opportunities exist for science and enterprises to combine to develop the excellent varieties needed by the market to attract investments from investors. However, the backward rural areas in the west are limited by the low level of technology and infrastructure construction; therefore, they need to lay a solid foundation to achieve effective results. Hypothesis 3 is proposed as follows.

Hypothesis 3. Digital inclusive finance is conducive to widening the net income gap between urban and rural residents, and a regional differentiation effect exists. 
Property income [23] mainly refers to income from investments and financial management. Because urban residents are exposed to a higher number of investment choices from large financial institutions, digital inclusive finance is mostly targeted at the long tail group excluded from traditional finance, especially rural residents. Farmers can use idle funds to lock in a high interest rate by buying savings insurance, obtain financial income by buying fund products, or acquire dividend income by participating in leading enterprises. In this way, digital inclusive finance can effectively narrow the urban-rural property income gap. In terms of regional differences, because rural residents in the eastern region have more flexible minds and greater financial knowledge, they are more likely to invest profitably. However, even if they have no investment constraints, rural residents in the western region are restricted by subjective self-exclusion and the objective "digital divide." Therefore, digital inclusive finance has a stronger effect on narrowing the urban-rural property income gap in the eastern region than in the western region [24-26]. Hypothesis 4 is proposed as follows.

Hypothesis 4. Digital inclusive finance is conducive to narrowing the urban-rural property income gap, and a regional differentiation effect exists.

Generally, transfer income is expenditure at the national level; therefore, it is closely related to fiscal funds. Digital inclusive finance can significantly promote the growth of local tax revenue by expanding the tax base and improving the efficiency of tax collection [27], such that the funds used for social security expenditures also increase accordingly. Because rural residents are more likely than urban residents to benefit from social security, digital inclusive finance is expected to narrow the urban-rural transfer income gap. From the perspective of regional differences, the coverage of transfer income in the eastern region has been very extensive, but the demand and shortfall for this income are larger in the poor parts of the west. Therefore, the development of digital inclusive finance has a weaker effect on narrowing the urban-rural transfer income gap in the eastern and central regions than in the western regions. Hypothesis 5 is proposed as follows:

Hypothesis 5. Digital inclusive finance is conducive to narrowing the urban-rural transfer income gap, and a long tail effect between regions exists.

Wage income has always been the most important part of urban residents' source of income, and its contribution to the overall income gap is the greatest. Although the net operating income, property income, and transfer income gaps are less influential, they are still part of the total income gap between urban and rural residents [28]. In the current context, wage, property, and transfer income in cities and towns are far higher than those in rural areas, whereas the opposite is true for net operating income. Therefore, narrowing the income gap of the first three and expanding the net operating income gap will help narrow the overall income gap thus, digital inclusive finance will not only directly influence per capita disposable income gap but also impose an indirect impact on the overall income gap through the wage income, net operating income, property income, and transfer income gaps-a mediating effect [11]. Therefore, the paper puts forward Hypothesis 6 as follows.

Hypothesis 6. Digital inclusive finance reduces the income gap between urban and rural residents by narrowing the wage income, property income, and transfer income gaps and expanding the net operating income gap.

\subsection{Variable Selection}

The variables in this paper mainly include explained variables, core explanatory variables, and control variables. The details are as follows. 


\subsubsection{Explained Variables: Urban-Rural Gap of Total Income and Income Structure}

In the existing academic research, four methods are commonly used to measure the income gap between urban and rural residents. The first method is the absolute income gap, which is the difference between urban and rural disposable income per person. However, describing the relative degree of the income gap is difficult because of the large income gap among provinces. The second method is the Gini coefficient derived from the Lorenz curve. Although this value can reflect the overall income gap, measuring the contribution of the inter-group and intra-group gaps to the overall income gap is difficult. Third, the relative income gap is the ratio of urban to rural per capita disposable income. The data for this method are easy to obtain and intuitive but cannot reflect the influence caused by the change in the proportion of the urban and rural populations [29-31]. The fourth method is the Theil index, whose most significant advantage lies in the additional decomposabilitythe ability to decompose the urban-rural gap from the total gap. Simultaneously, the Theil index can reflect the changes in urban and rural income polarization and consider demographic factors [32-34]. This paper combines the popular practices in the existing literature and uses the Theil-T index to measure the total urban-rural income gap. The specific formula is as follows:

$$
\text { theil }_{i, t}=\sum_{j=1}^{2}\left[\left(\frac{Y_{i j, t}}{Y_{i, t}}\right) \times \ln \left(\frac{\frac{Y_{i j, t}}{Y_{i, t}}}{\frac{P_{i j, t}}{P_{i, t}}}\right)\right]
$$

where $j=1$ represents the town and $j=2$ represents the countryside. $Y_{i, t}$ represents the disposable income of year $t$ in region $i$, and $Y_{i j, t}$ represents the disposable income of urban or rural residents in year $t$ in region $i . P_{i, t}$ denotes the total population of region $i$ in year $t$, and $P_{i j, t}$ denotes the number of urban or rural residents in region $i$ in year $t$. The higher the Theil index, the wider the income gap between urban and rural residents. The itemized income gap can be calculated only by replacing the $Y_{i, t}$ and $Y_{i j, t}$ total income variables with the relevant variables of the four sources of income-wage income, net operating income, property income, and transfer income.

\subsubsection{Core Explanatory Variable: Index of Digital Inclusive Finance}

In April 2019, the second issue of the Peking University Digital Inclusive Finance Index was released. The index covers data in 31 provinces of China from 2011 to 2018, which accurately reflects the development status and evolution trend of digital inclusive finance [35]. Therefore, the empirical research in this paper refers to the index. Because the value of the original data was too large, the percentage of the index using 100 was used as the subsequent regression data.

\subsubsection{Control Variables}

Based on the review of existing literature, this paper divides the control variables into the following three parts. The first part is economic development, including two variables. In economics, GDP per capita is often used as an indicator to measure economic development and is the ratio of a region's total GDP to total population [36]. In 1955, American economist Kuznets put forward the inverted U-shaped curve hypothesis, arguing that income distribution first deteriorated and then improved as the economy developed. To test the applicability of this theory in China, the logarithm of regional per capita GDP and its square are introduced to describe economic growth. However, this theory is still controversial. Some scholars, such as Han and Han believe that Chinese resident's income level has not reached the inflection point mentioned by Kuznets [19]; therefore, the expected impact of economic development on income distribution is uncertain.

The second part is about policies, which mainly considers the two indicators of fixed asset investment bias and agricultural support. The former is the ratio of total fixed assets to regional GDP. Generally, under a policy of giving priority to urban development, fixed 
asset investments tend to have a strong urban bias. However, after empirical tests, some scholars found that this indicator accelerated urbanization, which was conducive to rural labor force employment transfers and labor price equalization [37], thus narrowing the income gap. In conclusion, the influence of this variable on the urban-rural income gap is uncertain. Agricultural support is the ratio of governmental agriculture, forestry, and water expenditures to the local general public budget. Because the index tends to have a strong rural bias, it is negatively correlated with the urban-rural income gap.

The third part is other control factors, primarily the two indicators of human capital and industrial structure. At present, many scholars use the "average years of education" index to measure human capital. However, this index is based on sample data from the national census of population change, and its sampling ratio is less than $0.1 \%$, which is not representative and might lead to large randomness. The proportion of junior college and undergraduate students in the total population can be appropriately used to measure human capital [38], as referenced in Li and Shang. The higher the human capital, the better the opportunity for rural labor to receive an education, move to the city, and promote the balanced adjustment of the labor market structure to narrow the urban-rural income gap. The industrial structure is measured by the ratio of the sum of the added value of the secondary industry and the added value of the tertiary industry to regional GDP. Most of the secondary and tertiary industries in developing countries are labor-intensive. Therefore, the development of these two industries is conducive to absorbing rural surplus labor and narrowing the income gap.

\subsection{Data Source and Processing}

Data for the core explanatory variables come from the Digital Inclusive Finance Index of Peking University. Data for provincial control variables, urban and rural per capita disposable income, and income structure were obtained from the China Statistical Yearbook, and very few outliers were replaced by corresponding data from Wind. The National Bureau of Statistics changed the statistical caliber in 2013: "Rural per capita net income" was revised to "Rural per capita disposable income" and "urban per capita disposable income" remained; therefore, the stability and comparability of the data can be guaranteed in the sample time interval. The Shanghai, Hubei, Hainan, Yunnan, Gansu, and Tibet provinces were excluded because of missing data, and 25 provinces in mainland China from 2014 to 2018 were selected as samples. The excluded provinces were evenly distributed in the eastern, central, and western parts of China (the division of eastern, central and western China in this paper is based on the China Statistical Yearbook of 2019. The western region includes 12 provincial-level administrative regions, namely Sichuan, Chongqing, Guizhou, Yunnan, Tibet, Shaanxi, Gansu, Qinghai, Ningxia, Xinjiang, Guangxi and Inner Mongolia. The central region has eight provincial-level administrative regions, namely Shanxi, Jilin, Heilongjiang, Anhui, Jiangxi, Henan, Hubei and Hunan. The eastern region consists of 11 provincial-level administrative regions, namely Beijing, Tianjin, Hebei, Liaoning, Shanghai, Jiangsu, Zhejiang, Fujian, Shandong, Guangdong and Hainan.), indicating that their impact on the overall estimate is not significant, and the results are still reliable. Table 1 provides the descriptive statistical results of the main variables. 
Table 1. Descriptive Statistical Results of Main Variables.

\begin{tabular}{|c|c|c|c|c|c|}
\hline Variable Sign & Variable Implication & Mean & Std & Minimum & Maximum \\
\hline theil & Disposable Income Gap & 1.4551 & 0.4052 & 0.7369 & 2.7062 \\
\hline theil_inc & Wage Income Gap & 1.5954 & 0.5345 & 0.7435 & 3.2522 \\
\hline theil_ope & $\begin{array}{l}\text { Net Operating } \\
\text { Income Gap }\end{array}$ & 1.9242 & 0.7867 & 0.9783 & 4.2709 \\
\hline theil_pro & Property Income Gap & 1.7298 & 0.9201 & 0.0666 & 4.6666 \\
\hline theil_tra & Transfer Income Gap & 0.1342 & 0.0593 & 0.0438 & 0.3081 \\
\hline szph & $\begin{array}{l}\text { Digital Inclusive } \\
\text { Finance }\end{array}$ & 2.4011 & 0.4705 & 1.4593 & 3.6854 \\
\hline gdp & $\begin{array}{l}\text { Logarithmic of Per } \\
\text { Capita GDP }\end{array}$ & 10.9062 & 0.3687 & 10.1825 & 11.8509 \\
\hline gdp2 & $\begin{array}{l}\text { Logarithmic of Per } \\
\text { Capita GDP2 }\end{array}$ & 119.0789 & 8.1346 & 103.6837 & 140.4439 \\
\hline invest & Fixed Assets Bias & 0.7888 & 0.2293 & 0.2637 & 1.3554 \\
\hline policy & Agricultural Support & 0.1156 & 0.0316 & 0.0435 & 0.1897 \\
\hline education & Human Capital & 0.0199 & 0.0048 & 0.0090 & 0.0335 \\
\hline industry & Industrial Structure & 0.9115 & 0.0429 & 0.8135 & 0.9961 \\
\hline
\end{tabular}

As Table 1 shows, each income gap is not evenly distributed in the overall disposable income gap with its own characteristics. In terms of the Pearson's correlation coefficient matrix, most of the correlation coefficients between the variables are less than 0.8 , indicating that no multicollinearity problem exists. Most variables are significantly correlated with each other at the $5 \%$ significant level, which lays a foundation for the regression analysis in the remainder of the paper.

\subsection{Econometric Model}

For Hypothesis 1, the impact of digital inclusive finance on the urban-rural income gap is first tested. Although the six control variables have been introduced, it is inevitable that variables are missing because of the numerous factors that affect the urban-rural income gap. Therefore, this paper examines individual heterogeneity factors from the provincial level to alleviate the endogenous problems that they caused. In addition, because China put forward the "new normal" in 2014, balanced development among regions has been consistently stable. Therefore, factors such as policies that change over time seldom fluctuate, and the time-point effect can be temporarily ignored. Therefore, the following fixed effect model is established:

$$
\text { theil } l_{i t}=\alpha_{0}+\alpha_{1} s z p h_{i t}+\alpha_{2} X_{i t}+\theta_{i}+\varepsilon_{i t}
$$

where $t_{\text {eit }} i$ is the explained variable representing the urban-rural income gap in province $i$ in year $t . s z p h_{i t}$ is the core explanatory variable, which represents the digital inclusive finance index of province $i$ in year $t$. $X_{i t}$ represents other control variables, $\theta_{i}$ represents the provincial fixed effect, and $\varepsilon_{i t}$ represents the stochastic disturbance.

For Hypotheses 2-5, the explained variables of the baseline model are slightly changed to form the following fixed effect model:

$$
\text { theil_(inc/ope/pro/tra })_{i t}=\delta_{0}+\delta_{1} s z p h_{i t}+\delta_{2} X_{i t}+\theta_{i}+\varepsilon_{i t}
$$

where theil_inc $i t$, theil_ope $i_{i t}$, theil_pro ${ }_{i t}$, and theil_tra $a_{i t}$ represent urban-rural wage income gap, urban-rural net operating income gap, urban-rural property income gap, and urbanrural transfer income gap, respectively, and the rest are the same as for the baseline regression model.

To verify Hypothesis 6, the following model is established on the basis of the previous two models:

$$
\text { theil } \left.\text { it }=\beta_{0}+\beta_{1} \text { theil_(inc/ope/pro/tra }\right)_{i t}+\beta_{2} s z p h_{i t}+\beta_{3} X_{i t}+\theta_{i}+\varepsilon_{i t}
$$


where $\alpha_{1}$ represents the total effect of digital inclusive finance on narrowing the urbanrural disposable income gap, $\beta_{2}$ represents the direct effect of digital inclusive finance on narrowing the urban-rural disposable income gap, $\delta_{1} \beta_{1}$ represents the mediating effect, and $\delta_{1} \beta_{1} / \alpha_{1}$ represents the proportion of the mediating effect in the total effect. In this paper, a stepwise regression method is used to estimate the model. If $\alpha_{1}, \beta_{1}$, and $\beta_{2}$ are significant, but $\beta_{2}$ is smaller than $\alpha_{1}$, then a partial mediating effect exists. If both $\alpha_{1}$ and $\beta_{1}$ are significant but $\beta_{2}$ is not significant, then a complete mediating effect exists [39-42].

\section{Results}

\subsection{Benchmark Regression Model Estimation-A Test of H1}

The regression estimation is performed on the baseline regression model (2), and the results are shown in Table 2. Considering the heteroskedasticity, the standard deviations after clustering robust standard errors are reported below. Model 1 first presents the regression results of mixed OLS as a reference. In this model, although digital inclusive finance passed the $10 \%$ significance level test, it is positive, indicating that it has a positive impact on the urban-rural income gap, which is contrary to Hypothesis 1 . Therefore, the individual effect is suspected of causing inaccurate estimation results. After introducing the provincial individual fixed effect, the F statistic value is 180.85 , and the individual homogeneity hypothesis is rejected at the $1 \%$ level. Therefore, the fixed effect model should be used. This paper introduces the control variables one by one to clearly show the influence of the control variables on the estimated results and to test the robustness of the results. In model 2, only the impact of digital inclusive finance on the urban-rural disposable income gap is studied. Model 3 introduces the economic development control variables on the basis of model 2. The logarithm of per capita GDP and its square are significantly negative and positive at the $1 \%$ level, respectively, indicating that economic growth and income distribution are in a positive U-shaped curve relationship. The Kuznets hypothesis is not valid in China, which is the same conclusion reached by scholars such as Zhang [19]. Model 4 continues to introduce the policy factor on the basis of model 3, which finds that the economic development factor is still significant, and the fixed asset investment at the $5 \%$ significance level is helpful in narrowing the urban-rural income gap. However, the coefficient of agricultural support intensity is not significant. Model 5 introduces other control variables, and human capital and industrial structure do not pass the significance test. Model 6 has the same variables as Model 5 but is estimated using the least squares dummy variable (LSDV) method. The results show that most of the individual dummy variables passed the $1 \%$ significance test, indicating the establishment of the fixed effect. However, the joint significance test of time-point dummy variables accepted the null hypothesis and rejected the bidirectional fixed effect. The Hausman test rejects the random effect, thus indicating the adoption of the individual unidirectional fixed effect.

From the regression results of models 2 to 5 , digital inclusive finance has a significant narrowing effect on the urban-rural income gap regardless of the number of control variables added. According to models 7-9, digital inclusive finance was found to have the most significant and largest narrowing effect on the income gap in the western region, and has little impact on the eastern and central regions, indicating the existence of a disequilibrium effect. Therefore, Hypothesis 1 is true. 
Table 2. Baseline Regression Results.

\begin{tabular}{|c|c|c|c|c|c|c|c|c|c|}
\hline & Model 1 & Model 2 & Model 3 & Model 4 & Model 5 & Model 6 & Model 7 & Model 8 & Model 9 \\
\hline \multirow[t]{2}{*}{ szph } & 0.0776 * & $-0.113^{* * *}$ & $-0.057^{* * *}$ & $-0.063^{* * *}$ & $-0.0566^{* * *}$ & $-0.0566^{* *}$ & -0.0404 & -0.0103 & $-0.060 * * *$ \\
\hline & $(0.0436)$ & (0.0190) & $(0.0158)$ & $(0.0180)$ & $(0.0198)$ & $(0.0222)$ & $(0.0263)$ & $(0.0265)$ & $(0.0170)$ \\
\hline \multirow[t]{2}{*}{ gdp } & $-16.31 * * *$ & & $-7.990 * * *$ & $-8.014 * * *$ & $-7.049 * * *$ & $-7.049^{* * *}$ & -2.506 & 7.951 & $-13.48^{* * *}$ \\
\hline & (5.541) & & (1.825) & (1.851) & (1.696) & (1.902) & $(2.404)$ & $(9.448)$ & $(2.101)$ \\
\hline \multirow[t]{2}{*}{ gdp2 } & $0.710^{* * *}$ & & $0.354^{* * *}$ & $0.356^{* * *}$ & $0.312 * * *$ & $0.312^{* * *}$ & 0.113 & -0.390 & $0.607 * * *$ \\
\hline & $(0.250)$ & & $(0.0812)$ & (0.0833) & $(0.0766)$ & $(0.0859)$ & (0.109) & $(0.448)$ & $(0.0964)$ \\
\hline \multirow[t]{2}{*}{ invest } & $0.516^{* *}$ & & & $-0.0565 * *$ & -0.00943 & -0.00943 & -0.0127 & 0.0030 & -0.0528 \\
\hline & $(0.190)$ & & & $(0.0229)$ & $(0.0387)$ & $(0.0434)$ & $(0.0380)$ & $(0.0272)$ & $(0.0703)$ \\
\hline \multirow[t]{2}{*}{ policy } & -2.443 & & & 0.160 & 0.234 & 0.234 & 0.955 & 0.316 & -0.137 \\
\hline & $(1.510)$ & & & $(0.336)$ & $(0.291)$ & $(0.327)$ & $(1.247)$ & $(0.373)$ & $(0.318)$ \\
\hline \multirow[t]{2}{*}{ education } & -8.817 & & & & -13.12 & -13.12 & $-35.52 * *$ & $-25.89^{* * *}$ & 1.896 \\
\hline & $(8.486)$ & & & & $(10.16)$ & $(11.40)$ & (15.36) & (4.693) & $(8.887)$ \\
\hline \multirow[t]{2}{*}{ industry } & -2.054 & & & & 0.721 & 0.721 & -0.593 & 0.210 & 0.349 \\
\hline & (1.603) & & & & $(0.533)$ & $(0.598)$ & $(1.511)$ & $(0.623)$ & $(0.339)$ \\
\hline \multirow[t]{2}{*}{ constant } & $96.49 * * *$ & $1.727^{* * *}$ & $46.59^{* * *}$ & $46.59 * * *$ & $40.95^{* * *}$ & $40.38^{* * *}$ & 16.30 & -38.51 & $76.35^{* * *}$ \\
\hline & $(30.67)$ & $(0.0456)$ & $(10.23)$ & $(10.28)$ & (9.175) & $(10.22)$ & (13.15) & (50.08) & (11.59) \\
\hline Sample & 125 & 125 & 125 & 125 & 125 & 125 & 45 & 35 & 45 \\
\hline $\mathbf{R}^{2}$ & 0.787 & 0.559 & 0.792 & 0.800 & 0.818 & 0.996 & 0.519 & 0.923 & 0.946 \\
\hline Method & OLS & FE & FE & FE & FE & LSDV & $\mathrm{FE}$ & FE & $\mathrm{FE}$ \\
\hline Region & Overall & Overall & Overall & Overall & Overall & Overall & East & Central & West \\
\hline
\end{tabular}

Note: ${ }^{* *}$ indicates significance at the $1 \%$ level, ${ }^{* *}$ indicates significance at the $5 \%$ level, and * indicates significance at the $10 \%$ level. The values in brackets are the clustering robust standard errors of the estimation coefficients of each variable-the same as below.

\subsection{Estimation of the Baseline Model Variant-Test of $\mathrm{H} 2, \mathrm{H} 3, \mathrm{H} 4$, and $\mathrm{H} 5$}

The baseline regression results show that digital inclusive finance is beneficial to narrowing the disposable income gap; however, will the conclusion change when it comes to specific income? The seven models in Table 3 effectively show that digital inclusive finance is conducive to alleviating the urban-rural wage income gap. In terms of the marginal effect, as digital inclusive finance increases by 100 units, the wage income gap decreases by 0.122 units. In terms of heterogeneity, digital inclusive finance has the strongest force on the western region, and the force on the eastern and central regions is approximately the same, proving the existence of the long tail effect and verifying Hypothesis 2.

Table 3. Regression Results of Wage Income Gap.

\begin{tabular}{|c|c|c|c|c|c|c|c|}
\hline & Model 1 & Model 2 & Model 3 & Model 4 & Model 5 & Model 6 & Model 7 \\
\hline szph & $\begin{array}{c}-0.196^{* * *} \\
(0.0348)\end{array}$ & $\begin{array}{c}-0.123 \text { *** } \\
(0.0185)\end{array}$ & $\begin{array}{c}-0.141^{* * *} \\
(0.0241)\end{array}$ & $\begin{array}{c}-0.122^{* * *} \\
(0.0285)\end{array}$ & $\begin{array}{c}-0.0724^{* *} \\
(0.0271)\end{array}$ & $\begin{array}{c}-0.0703^{* * *} \\
(0.0126)\end{array}$ & $\begin{array}{c}-0.160 \text { ** } \\
(0.0497)\end{array}$ \\
\hline gdp & & $\begin{array}{c}-16.21^{* * *} \\
(2.318)\end{array}$ & $\begin{array}{c}-16.35^{* * *} \\
(2.180)\end{array}$ & $\begin{array}{c}-14.07^{* * *} \\
(2.025)\end{array}$ & $\begin{array}{c}-5.662 * * * \\
(1.365)\end{array}$ & $\begin{array}{l}-4.631 \\
(11.53)\end{array}$ & $\begin{array}{c}-20.93 * * * \\
(3.227)\end{array}$ \\
\hline gdp2 & & $\begin{array}{c}0.727^{* * *} \\
(0.103)\end{array}$ & $\begin{array}{c}0.738^{* * *} \\
(0.0983)\end{array}$ & $\begin{array}{l}0.633^{* * *} \\
(0.0920)\end{array}$ & $\begin{array}{l}0.261^{* * *} \\
(0.0608)\end{array}$ & $\begin{array}{c}0.199 \\
(0.542)\end{array}$ & $\begin{array}{c}0.950 * * * \\
(0.152)\end{array}$ \\
\hline invest & & & $\begin{array}{c}-0.165^{* * *} \\
(0.0351)\end{array}$ & $\begin{array}{l}-0.0702 \\
(0.0571)\end{array}$ & $\begin{array}{l}-0.0502 \\
(0.0398)\end{array}$ & $\begin{array}{c}-0.0688^{*} \\
(0.0324)\end{array}$ & $\begin{array}{c}-0.0701 \\
(0.116)\end{array}$ \\
\hline policy & & & $\begin{array}{c}0.604 \\
(0.485)\end{array}$ & $\begin{array}{c}0.580 \\
(0.450)\end{array}$ & $\begin{array}{c}1.259 \\
(0.957)\end{array}$ & $\begin{array}{c}0.827 \\
(0.480)\end{array}$ & $\begin{array}{c}0.622 \\
(0.859)\end{array}$ \\
\hline education & & & & $\begin{array}{c}-26.79 * \\
(13.88)\end{array}$ & $\begin{array}{c}-57.09^{* *} \\
(17.78)\end{array}$ & $\begin{array}{c}-52.78^{* *} \\
(18.30)\end{array}$ & $\begin{array}{l}-9.720 \\
(12.51)\end{array}$ \\
\hline industry & & & & $\begin{array}{c}0.621 \\
(0.555)\end{array}$ & $\begin{array}{l}-1.497 \\
(0.920)\end{array}$ & $\begin{array}{l}-0.620 \\
(0.440)\end{array}$ & $\begin{array}{c}0.614 \\
(0.710)\end{array}$ \\
\hline constant & $\begin{array}{l}2.067^{* * *} \\
(0.0835)\end{array}$ & $\begin{array}{c}92.10^{* * *} \\
(13.03)\end{array}$ & $\begin{array}{c}92.44^{* * *} \\
(12.08)\end{array}$ & $\begin{array}{c}79.91 * * * \\
(10.81)\end{array}$ & $\begin{array}{c}34.47^{* * *} \\
(7.490)\end{array}$ & $\begin{array}{c}30.16 \\
(61.75)\end{array}$ & $\begin{array}{c}117.0 * * * \\
(17.51)\end{array}$ \\
\hline Sample Size & 125 & 125 & 125 & 125 & 45 & 35 & 45 \\
\hline $\mathbf{R}^{2}$ & 0.565 & 0.852 & 0.876 & 0.894 & 0.776 & 0.961 & 0.934 \\
\hline Method & FE & FE & FE & FE & FE & FE & FE \\
\hline Region & Overall & Overall & Overall & Overall & East & Central & West \\
\hline
\end{tabular}


As the regression results in Table 4 show, although a positive correlation exists between digital inclusive finance and the net operating income gap, the results are not significant after the addition of control variables, which refutes Hypothesis 3. Emerging digital inclusive finance does not significantly affect the net operating income gap.

Table 4. Regression Results of Net Operating Income Gap.

\begin{tabular}{|c|c|c|c|c|c|c|c|}
\hline & Model 1 & Model 2 & Model 3 & Model 4 & Model 5 & Model 6 & Model 7 \\
\hline \multirow[t]{2}{*}{ szph } & 0.180 * & -0.00188 & -0.0479 & -0.0539 & -0.172 & -0.121 & 0.0121 \\
\hline & $(0.104)$ & $(0.0467)$ & $(0.0604)$ & $(0.0624)$ & $(0.184)$ & $(0.0797)$ & $(0.0671)$ \\
\hline \multirow[t]{2}{*}{ gdp } & & -20.50 & -21.97 & -22.80 & $-73.83^{*}$ & $80.83 *$ & -0.225 \\
\hline & & $(20.23)$ & $(20.72)$ & $(21.52)$ & $(37.54)$ & $(38.14)$ & $(6.697)$ \\
\hline \multirow[t]{2}{*}{ gdp2 } & & 0.980 & 1.056 & 1.094 & $3.346^{*}$ & $-3.757^{*}$ & 0.0189 \\
\hline & & $(0.940)$ & $(0.970)$ & $(1.008)$ & (1.692) & $(1.779)$ & $(0.298)$ \\
\hline \multirow[t]{2}{*}{ invest } & & & -0.0392 & -0.0772 & 0.115 & 0.298 & 0.00414 \\
\hline & & & $(0.142)$ & $(0.206)$ & $(0.337)$ & $(0.164)$ & $(0.265)$ \\
\hline \multirow[t]{2}{*}{ policy } & & & 2.782 & 2.749 & $16.56^{*}$ & 0.807 & 0.0862 \\
\hline & & & (2.694) & $(2.456)$ & $(8.462)$ & $(1.448)$ & (1.736) \\
\hline \multirow[t]{2}{*}{ education } & & & & 10.66 & -158.9 & -13.50 & 14.03 \\
\hline & & & & (29.95) & $(223.6)$ & (31.10) & $(26.53)$ \\
\hline \multirow[t]{2}{*}{ industry } & & & & -0.451 & 23.92 & 3.771 & $2.401 * *$ \\
\hline & & & & $(2.397)$ & (16.05) & $(2.198)$ & $(0.947)$ \\
\hline \multirow[t]{2}{*}{ constant } & $1.492^{* * *}$ & 108.9 & 115.6 & 120.4 & $388.5^{*}$ & $-435.7 *$ & -0.426 \\
\hline & $(0.250)$ & (108.7) & (110.4) & (116.1) & (203.8) & $(205.6)$ & $(37.93)$ \\
\hline Sample Size & 125 & 125 & 125 & 125 & 45 & 35 & 45 \\
\hline $\mathbf{R}^{2}$ & 0.0912 & 0.212 & 0.219 & 0.220 & 0.367 & 0.566 & 0.168 \\
\hline Method & FE & FE & FE & FE & FE & FE & FE \\
\hline Region & Overall & Overall & Overall & Overall & East & Central & West \\
\hline
\end{tabular}

The regression results in Table 5 show that digital inclusive finance is conducive to narrowing the urban-rural property income gap and has the strongest effect on the eastern part but no significant effect on the central and western parts. This finding also supports Hypothesis 4 , indicating that digital inclusive finance has a regional differentiation effect on the property income gap.

Table 5. Regression Results of Property Income Gap.

\begin{tabular}{|c|c|c|c|c|c|c|c|}
\hline & Model 1 & Model 2 & Model 3 & Model 4 & Model 5 & Model 6 & Model 7 \\
\hline szph & $\begin{array}{c}-0.286^{* * *} \\
(0.0428)\end{array}$ & $\begin{array}{c}-0.156^{* * *} \\
(0.0383)\end{array}$ & $\begin{array}{c}-0.142 \text { *** } \\
(0.0497)\end{array}$ & $\begin{array}{c}-0.166^{* *} \\
(0.0592)\end{array}$ & $\begin{array}{l}-0.103 * \\
(0.0767)\end{array}$ & $\begin{array}{l}-0.0234 \\
(0.0787)\end{array}$ & $\begin{array}{c}-0.114 \\
(0.0815)\end{array}$ \\
\hline gdp & & $\begin{array}{c}-15.85^{* * *} \\
(4.330)\end{array}$ & $\begin{array}{c}-15.25^{* * *} \\
(4.520)\end{array}$ & $\begin{array}{c}-16.48^{* * *} \\
(4.672)\end{array}$ & $\begin{array}{c}5.733 \\
(9.715)\end{array}$ & $\begin{array}{c}-19.93 * \\
(9.648)\end{array}$ & $\begin{array}{c}-36.90^{* * *} \\
(4.009)\end{array}$ \\
\hline gdp2 & & $\begin{array}{c}0.697^{* * * *} \\
(0.199)\end{array}$ & $\begin{array}{c}0.667^{* * *} \\
(0.210)\end{array}$ & $\begin{array}{c}0.722 * * * \\
(0.217)\end{array}$ & $\begin{array}{l}-0.248 \\
(0.436)\end{array}$ & $\begin{array}{l}0.895 \text { * } \\
(0.447)\end{array}$ & $\begin{array}{c}1.654^{* * * *} \\
(0.188)\end{array}$ \\
\hline invest & & & $\begin{array}{c}-0.0493 \\
(0.121)\end{array}$ & $\begin{array}{c}-0.0687 \\
(0.111)\end{array}$ & $\begin{array}{l}-0.102 \\
(0.103)\end{array}$ & $\begin{array}{c}-0.122 \\
(0.0645)\end{array}$ & $\begin{array}{l}-0.235 \\
(0.285)\end{array}$ \\
\hline policy & & & $\begin{array}{l}-1.027 \\
(1.598)\end{array}$ & $\begin{array}{l}-0.536 \\
(1.251)\end{array}$ & $\begin{array}{l}-1.293 \\
(2.044)\end{array}$ & $\begin{array}{c}0.579 \\
(0.531)\end{array}$ & $\begin{array}{l}-2.222 \\
(2.274)\end{array}$ \\
\hline education & & & & $\begin{array}{c}5.310 \\
(19.43)\end{array}$ & $\begin{array}{l}-34.67 \\
(25.54)\end{array}$ & $\begin{array}{c}-39.78^{* *} \\
(11.59)\end{array}$ & $\begin{array}{l}52.80 * * \\
(20.89)\end{array}$ \\
\hline industry & & & & $\begin{array}{c}2.321 \\
(1.776)\end{array}$ & $\begin{array}{c}-8.582 * \\
(4.110)\end{array}$ & $\begin{array}{l}-1.860 \\
(1.097)\end{array}$ & $\begin{array}{c}3.315 \\
(2.488)\end{array}$ \\
\hline constant & $\begin{array}{c}2.491^{* * *} \\
(0.103)\end{array}$ & $\begin{array}{c}92.00 * * * \\
(23.57)\end{array}$ & $\begin{array}{c}89.11^{* * *} \\
(24.33)\end{array}$ & $\begin{array}{c}93.92 \text { *** } \\
(24.84)\end{array}$ & $\begin{array}{l}-22.60 \\
(51.76)\end{array}$ & $\begin{array}{l}115.5^{*} \\
(52.53)\end{array}$ & $\begin{array}{c}204.7^{* * *} \\
(21.75)\end{array}$ \\
\hline Sample Size & 125 & 125 & 125 & 125 & 45 & 35 & 45 \\
\hline $\mathbf{R}^{2}$ & 0.602 & 0.773 & 0.777 & 0.785 & 0.696 & 0.965 & 0.865 \\
\hline Method & FE & FE & FE & FE & FE & FE & FE \\
\hline Region & Overall & Overall & Overall & Overall & East & Central & West \\
\hline
\end{tabular}


According to the results in Table 6, digital inclusive finance is conducive to narrowing the urban-rural transfer income gap.

Table 6. Regression Results of Transfer Income Gap.

\begin{tabular}{|c|c|c|c|c|c|c|c|}
\hline & Model 1 & Model 2 & Model 3 & Model 4 & Model 5 & Model 6 & Model 7 \\
\hline szph & $\begin{array}{l}-0.00342 \\
(0.00646)\end{array}$ & $\begin{array}{c}-0.0320 * * * \\
(0.0104)\end{array}$ & $\begin{array}{l}-0.0150 * * \\
(0.00721)\end{array}$ & $\begin{array}{l}-0.0175^{*} \\
(0.00854)\end{array}$ & $\begin{array}{c}-0.00833 \\
(0.0152)\end{array}$ & $\begin{array}{l}-0.0253 \\
(0.0272)\end{array}$ & $\begin{array}{c}-0.0277 \text { * } \\
(0.0131)\end{array}$ \\
\hline gdp & & $\begin{array}{c}0.545 \\
(0.429)\end{array}$ & $\begin{array}{l}1.080 * \\
(0.576)\end{array}$ & $\begin{array}{c}1.002 \\
(0.731)\end{array}$ & $\begin{array}{c}0.115 \\
(1.455)\end{array}$ & $\begin{array}{l}15.36 * \\
(7.601)\end{array}$ & $\begin{array}{c}1.651 \\
(1.860)\end{array}$ \\
\hline gdp2 & & $\begin{array}{l}-0.0187 \\
(0.0197)\end{array}$ & $\begin{array}{c}-0.0466^{*} \\
(0.0268)\end{array}$ & $\begin{array}{l}-0.0435 \\
(0.0336)\end{array}$ & $\begin{array}{c}-0.00695 \\
(0.0653)\end{array}$ & $\begin{array}{c}-0.720 * \\
(0.362)\end{array}$ & $\begin{array}{l}-0.0723 \\
(0.0869)\end{array}$ \\
\hline invest & & & $\begin{array}{c}0.0161 \\
(0.0181)\end{array}$ & $\begin{array}{c}0.0192 \\
(0.0246)\end{array}$ & $\begin{array}{l}0.0882 * * \\
(0.0298)\end{array}$ & $\begin{array}{l}-0.0160 \\
(0.0235)\end{array}$ & $\begin{array}{l}0.134^{* *} \\
(0.0476)\end{array}$ \\
\hline policy & & & $\begin{array}{c}-1.021^{* * * *} \\
(0.292)\end{array}$ & $\begin{array}{c}-0.942 * * * \\
(0.321)\end{array}$ & $\begin{array}{c}0.212 \\
(0.397)\end{array}$ & $\begin{array}{c}-0.999 * * * \\
(0.266)\end{array}$ & $\begin{array}{c}0.200 \\
(0.454)\end{array}$ \\
\hline education & & & & $\begin{array}{l}-0.724 \\
(3.261)\end{array}$ & $\begin{array}{l}-10.72 * * \\
(3.240)\end{array}$ & $\begin{array}{c}9.278 \\
(5.608)\end{array}$ & $\begin{array}{c}-9.061 \text { * } \\
(4.712)\end{array}$ \\
\hline industry & & & & $\begin{array}{c}0.402 \\
(0.514)\end{array}$ & $\begin{array}{c}2.102 * * * \\
(0.601)\end{array}$ & $\begin{array}{c}0.517 \\
(1.204)\end{array}$ & $\begin{array}{l}2.121 \text { ** } \\
(0.884)\end{array}$ \\
\hline constant & $\begin{array}{l}0.142 * * * \\
(0.0155)\end{array}$ & $\begin{array}{l}-3.504 \\
(2.342)\end{array}$ & $\begin{array}{c}-5.955 \text { * } \\
(3.096)\end{array}$ & $\begin{array}{l}-5.831 \\
(3.764)\end{array}$ & $\begin{array}{l}-2.093 \\
(7.702)\end{array}$ & $\begin{array}{c}-82.16 \text { * } \\
(40.38)\end{array}$ & $\begin{array}{c}-10.98 \\
(10.41)\end{array}$ \\
\hline Sample Size & 125 & 125 & 125 & 125 & 45 & 35 & 45 \\
\hline $\mathbf{R}^{2}$ & 0.00465 & 0.124 & 0.267 & 0.284 & 0.551 & 0.463 & 0.586 \\
\hline Method & FE & FE & FE & FE & $\mathrm{FE}$ & FE & $\mathrm{FE}$ \\
\hline Region & Overall & Overall & Overall & Overall & East & Central & West \\
\hline
\end{tabular}

Specifically, when digital inclusive finance increases by 100 units, the transfer income gap in the western region decreases by 0.0277 units, and the coefficients in the central and eastern regions lose statistical significance. Therefore, digital inclusive finance has a long tail effect, thus verifying Hypothesis 5.

\subsection{Mediating Effect Model Estimation-Test for H6}

In combination with the results of Tables 3-6, the narrowing mechanism of the overall income gap through the income structure is further considered. The results are provided in Table 7. Digital inclusive finance has a significant impact on the wage income, property income, and transfer income gaps. The direct effect of digital inclusive finance is smaller than the total effect; the three sub-income disparities significantly expand the urban-rural total income gap, indicating that part of the mediating effect is established. However, the impact of the net operating income gap on the total income gap did not even pass the $10 \%$ significance test, indicating that the mediating effect of net operating income does not exist. Additionally, the total effect of digital inclusive finance on alleviating the urbanrural disposable income gap is 0.0566 , and the mediating effect value of the wage income, property income, and transfer income gaps is $0.00572,0.0003$, and 0.00282, respectively, accounting for $10.11 \%, 0.52 \%$, and $4.98 \%$ of the total effect, respectively. Thus, digital inclusive finance is observed to primarily affect the total income gap by affecting the wage income gap. In conclusion, Hypothesis 6 is partially valid. 
Table 7. Mediating Effect.

\begin{tabular}{|c|c|c|c|c|c|}
\hline & Model 1 & Model 2 & Model 3 & Model 4 & Model 5 \\
\hline theil_inc & & $\begin{array}{l}0.0469 * \\
(0.0340)\end{array}$ & & & \\
\hline theil_ope & & & $\begin{array}{l}-0.0122 \\
(0.0168)\end{array}$ & & \\
\hline theil_pro & & & & $\begin{array}{l}0.00179 * \\
(0.00102)\end{array}$ & \\
\hline theil_tra & & & & & $\begin{array}{l}0.161^{* * *} \\
(0.0120)\end{array}$ \\
\hline szph & $\begin{array}{c}-0.0566^{* * *} \\
(0.0198)\end{array}$ & $\begin{array}{c}-0.0507^{* *} \\
(0.0192)\end{array}$ & $\begin{array}{c}-0.0572^{* * *} \\
(0.0196)\end{array}$ & $\begin{array}{c}-0.0284^{* * *} \\
(0.0144)\end{array}$ & $\begin{array}{l}-0.05^{* * *} \\
(0.0153)\end{array}$ \\
\hline gdp & $\begin{array}{c}-7.049 * * * \\
(1.696)\end{array}$ & $\begin{array}{c}0.0469 \\
(0.0340)\end{array}$ & $\begin{array}{c}-7.328^{* * * *} \\
(1.726)\end{array}$ & $\begin{array}{c}-6.976^{* * *} \\
(1.695)\end{array}$ & $\begin{array}{c}-6.149 * * * \\
(1.281)\end{array}$ \\
\hline gdp2 & $\begin{array}{l}0.312 * * * \\
(0.0766)\end{array}$ & $\begin{array}{c}-6.440 * * * \\
(1.654)\end{array}$ & $\begin{array}{l}0.325^{* * *} \\
(0.0778)\end{array}$ & $\begin{array}{l}0.308^{* * *} \\
(0.0766)\end{array}$ & $\begin{array}{l}0.274^{* * *} \\
(0.0574)\end{array}$ \\
\hline invest & $\begin{array}{c}-0.00943 \\
(0.0387)\end{array}$ & $\begin{array}{l}0.284^{* * *} \\
(0.0748)\end{array}$ & $\begin{array}{l}-0.0104 \\
(0.0390)\end{array}$ & $\begin{array}{c}-0.00731 \\
(0.0393)\end{array}$ & $\begin{array}{l}-0.0144 \\
(0.0314)\end{array}$ \\
\hline policy & $\begin{array}{c}0.234 \\
(0.291)\end{array}$ & $\begin{array}{l}0.00477 \\
(0.0394)\end{array}$ & $\begin{array}{c}0.267 \\
(0.295)\end{array}$ & $\begin{array}{c}0.261 \\
(0.278)\end{array}$ & $\begin{array}{c}0.305 \\
(0.305)\end{array}$ \\
\hline education & $\begin{array}{l}-13.12 \\
(10.16)\end{array}$ & $\begin{array}{c}0.375 \\
(0.285)\end{array}$ & $\begin{array}{l}-12.99 \\
(10.38)\end{array}$ & $\begin{array}{l}-13.44 \\
(10.31)\end{array}$ & $\begin{array}{l}-10.96 \\
(8.294)\end{array}$ \\
\hline industry & $\begin{array}{c}0.721 \\
(0.533)\end{array}$ & $\begin{array}{l}-12.73 \\
(9.785)\end{array}$ & $\begin{array}{c}0.716 \\
(0.525)\end{array}$ & $\begin{array}{c}0.846 \\
(0.547)\end{array}$ & $\begin{array}{c}0.437 \\
(0.603)\end{array}$ \\
\hline constant & $\begin{array}{c}40.95 \text { *** } \\
(9.175)\end{array}$ & $\begin{array}{c}0.624 \\
(0.496)\end{array}$ & $\begin{array}{c}42.43^{* * *} \\
(9.354)\end{array}$ & $\begin{array}{c}40.43^{* * *} \\
(9.201)\end{array}$ & $\begin{array}{c}35.60 * * * \\
(6.883)\end{array}$ \\
\hline Sample Size & 125 & 125 & 125 & 125 & 125 \\
\hline$R^{2}$ & 0.818 & 0.828 & 0.819 & 0.819 & 0.906 \\
\hline Method & FE & FE & FE & FE & FE \\
\hline Region & Overall & Overall & Overall & Overall & Overall \\
\hline
\end{tabular}

\subsection{Robustness Analysis}

Because of limited space, in this section, this paper does not report the regression results of the control variables but only shows the influence of digital inclusive finance on each explained variable.

These final models are estimated using the fixed effect method, which might ignore a model's potential endogeneity and lead to deviations in the coefficient estimation. For provinces with a significant disparity in income distribution between urban and rural residents, local governments are more likely to use digital inclusive finance to narrow the gap, indicating a two-way causality. Moreover, the digital inclusive finance index is compiled based on Ant Financial Services Group's internal data, which might not be representative enough, resulting in measurement errors. Finally, most users of Ant Financial products have individual characteristics, such as a willingness to accept new things and to take risks, which inevitably leads to the omission of relevant explanatory variables. Based on current popular research practices, this paper uses the ratio of the distance between each provincial capital and Hangzhou to the digital inclusive finance index, and the first-order lag of the digital inclusive finance index as two instrumental variables for the regression. Models $1-4$ of Table 8 report the estimation results of the instrumental variables using the two-stage least square method, and all of the instrumental variables pass the unidentifiable test, the weak instrumental variable test, and the over-identifiable constraint test. 
Table 8. Robustness Test.

\begin{tabular}{ccccccccc}
\hline & Model 1 & Model 2 & Model 3 & Model 4 & Model 5 & Model 6 & Model 7 & Model 8 \\
\hline theil & $-0.0723^{* * *}$ & $-0.0822^{* * *}$ & 0.0334 & $-0.0796^{* * *}$ & $-0.0140^{* * *}$ & -0.00766 & -0.00821 & $-0.0148^{* *}$ \\
& $(0.0185)$ & $(0.0280)$ & $(0.0457)$ & $(0.0211)$ & $(0.00434)$ & $(0.0130)$ & $(0.00887)$ & $(0.00614)$ \\
theil_inc & $-0.156^{* * *}$ & $-0.138^{* * *}$ & $-0.112^{*}$ & $-0.172^{* * *}$ & $-0.0396^{* * *}$ & -0.0114 & $-0.107^{* * *}$ & -0.0143 \\
& $(0.0245)$ & $(0.0265)$ & $(0.0585)$ & $(0.0465)$ & $(0.0105)$ & $(0.0210)$ & $(0.0248)$ & $(0.0411)$ \\
theil_ope & -0.153 & -0.301 & 0.158 & -0.0210 & -0.00442 & 0.00386 & $-0.0408^{* *}$ & -0.0197 \\
& $(0.129)$ & $(0.288)$ & $(0.202)$ & $(0.108)$ & $(0.00951)$ & $(0.0103)$ & $(0.0187)$ & $(0.0225)$ \\
theil_pro & $-0.208^{* * *}$ & $-0.169^{* *}$ & -0.0494 & $-0.164^{*}$ & $-0.129^{* * *}$ & $-0.113^{* * *}$ & -0.128 & $-0.168^{* * *}$ \\
& $(0.0511)$ & $(0.0673)$ & $(0.120)$ & $(0.0938)$ & $(0.0243)$ & $(0.0382)$ & $(0.0904)$ & $(0.0470)$ \\
theil_tra & $-0.0354^{* * *}$ & -0.0108 & -0.0722 & -0.00617 & $-0.0583^{* * *}$ & $-0.0424^{*}$ & $-0.135^{* *}$ & $-0.0446^{* * *}$ \\
& $(0.0130)$ & $(0.0159)$ & $(0.0449)$ & $(0.0202)$ & $(0.0143)$ & $(0.0209)$ & $(0.0575)$ & $(0.0135)$ \\
\hline Method & IV & IV & IV & IV & IV & IV & IV & IV \\
Variable & Theil-T & Theil-T & Theil-T & Theil-T & Theil-L & Theil-L & Theil-L & Theil-L \\
Region & Overall & East & Central & West & Overall & East & Central & West \\
\hline
\end{tabular}

Endogeneity has a minimal influence on the research results of this paper. One possible explanation is that digital inclusive finance as a new topic emerged in recent years, and the government has not regulated the area. Instead, it is temporarily allowed to develop, creating minimal two-way causality problems. At the same time, Ant Financial data cover a wide range of users, effectively preventing measurement errors and omissions of explanatory variables.

The Theil-T index is replaced by Theil-L index. Model 2 and model 3 estimations are repeated, and the results are shown in models 5-8 of Table 8 . All hypotheses are still valid, indicating that the conclusion is robust.

\section{Discussion}

The negative and significant relationship between digital inclusive finance and the overall income gap corroborates Hypothesis 1 of our work, which indicates that digital inclusive finance is beneficial to narrowing the total income gap. Then, we make use of fixed-effect panel data model to test the same relationship between digital inclusive finance and the wage income gap, property income gap and transfer income gap, which shows Hypotheses 2, 4 and 5 are confirmed. However, the digital inclusive finance has little effect on the net operating income gap between urban and rural residents, thus denying Hypothesis 3. Finally, we confirm Hypothesis 6 according to the results of mediating effect model. In these sub-items of income, we find that digital inclusive finance mainly narrows the overall income gap by narrowing the wage income gap. This is mainly because the Internet credit business directly alleviates the financing constraints of enterprises and drives the boom of returning home to start businesses. At the same time, digital payment service promotes consumption by improving payment efficiency, thus promoting production and investment of enterprises, which leads to a rise in wage income in rural areas. In the rest of this section, we analyze the results of each item of income and put forward corresponding suggestions. Then, we make an outlook for the future development of digital inclusive finance.

\subsection{Wage Income Gap Conclusion and Suggestion}

As the results in Table 3 show, first, digital credit provides ways to finance rural small and medium-sized enterprises that are excluded from obtaining traditional finance [43]. At the same time, digital payments can more significantly improve payment efficiency in rural areas and promote the production of enterprises by promoting consumption [44]. These two aspects jointly promote narrowing the wage income gap. Second, fewer traditional financial service branches operate in backward rural areas in western China; therefore, digital inclusive finance has a stronger impact in such areas. In other words, digital inclusive finance has a long tail effect on narrowing the wage income gap between urban 
and rural residents. Third, the results of Table 7 show that the nationwide mediating effect of wage income is most obvious, indicating that the main source of Chinese residents' current income is still wages, accounting for more than $40 \%$ of residents' disposable income.

Based on this analysis, the following suggestions are proposed for the wage income gap. First, the financing environment in eastern and central rural areas can be optimized, and small and micro enterprises can be promoted to provide jobs. Second, governments in eastern and central rural areas should focus on improving digital technology, accelerating the construction of multi-agency data platforms and shortening the assessment time for the personal credit of small and micro enterprise owners. Third, multi-level and multi-form Internet financing modes should be further explored to increase financing methods for small and micro enterprises.

\subsection{Net Operating Income Gap Conclusion and Suggestion}

The results in Table 4 show that digital inclusive finance does not have a substantial effect on the net operating income gap. A potential reason is the backward rural industry base. Even if farmers' funding constraints are alleviated, effectively improving farmers' net operating income is also difficult because of the geographical environment and investments in infrastructure that cannot be changed in the short term. In addition, given obvious operational risks, farmers are likely to again be excluded from accessing financial products; thus, they do not enjoy the dividends of digital inclusive finance.

In view of these issues, only by strengthening the foundation of industrial development and expanding the degree of industrial openness can the digital industry platform be fully utilized and farmers' net operating income be increased. First, local governments should expand coverage of the digital agricultural supply chain and increase industrial investments in transportation facilities or environmental transformation. Second, the combination of production, education, and research can be promoted, encouraging leading enterprises and scientific units to share technology or management experience to benefit the majority of small and medium-sized enterprises and avoid inefficient competition in the low-end market.

\subsection{Property Income Gap Conclusion and Suggestion}

As Table 5 shows, first, a large number of wealthy people live in Chinese cities and are beneficiaries of traditional money management services, whereas digital inclusive finance extends Internet money fund and intelligent investment services to relatively poor customers in rural areas, reducing the urban-rural property income gap. Second, compared with central and western rural areas, eastern rural areas and their better financial foundation and digital infrastructure give residents more abundant financial products from which to choose. In this context, farmers in eastern China are more inclined to benefit from emerging financial products $[30,31]$. Therefore, the impact of digital inclusive finance on the urban-rural property income gap has a regional differentiation effect. Because the property income gap is also a component of the urban-rural disposable income gap, narrowing the former is conducive to narrowing the latter.

The empirical results show that rural areas in central and western China fail to take full advantage of digital inclusive finance to increase property income. Therefore, these regions should further popularize financial knowledge, focus on improving rural residents digital skills, and take multiple measures to strengthen consumer education. Additionally, the government should strengthen the construction of digital infrastructure in rural areas and bridge the information gap with the eastern region to enable the fruits of development to be shared by all rather than only the eastern region.

\subsection{Transfer Income Gap Conclusion and Suggestion}

As the results in Table 6 show, first, under the strategic background of rural revitalization, the substantial funds brought by digital inclusive finance are given priority to rural residents, thus narrowing the urban-rural transfer income gap. Second, the western rural 
region is the focus of poverty alleviation and receives preferential treatment for government funds. Therefore, the impact of digital inclusive finance on the transfer income gap has a long tail effect. Because the transfer income gap is also a component of the urban-rural disposable income gap, its narrowing is also conducive to narrowing the latter. Third, transfer income in western rural areas has been significantly improved, whereas that in urban areas has already met residents' basic needs. Therefore, the central and eastern rural areas have become the weak links.

Based on this analysis, the recommendations are as follows. First, the Ministry of Human Resources and Social Security should make full use of the financial funds brought by digital inclusive finance to ensure basic needs in central and eastern rural areas [14]. Second, governments of the middle and eastern rural areas should further expand inclusive financial coverage to comprehensively promote employment, entrepreneurship, income, and consumption to increase the local fiscal revenue and, thus, the social security fund.

\subsection{Suggestions for Digital Inclusive Finance}

Digital inclusive finance, as a financial innovation means, is permeating all aspects of China's urban and rural economy, is affecting the urban-rural income distribution pattern, and is embodying a powerful effect in narrowing the urban-rural income gap. However, also to be noted is that the scale of today's digital inclusive finance business other than digital payments is still small. In the future, coverage breadth, depth and digitalization degree of digital inclusive finance should be improved, the construction of regulatory systems should be strengthened, and risk prevention systems, including policies and institutions, should be formulated [45-47].

\section{Conclusions}

First, from the perspective of total income, we discuss the narrowing effect of digital inclusive finance on the per capita disposable income gap between urban and rural residents and the disequilibrium effect among regions.

Second, this paper discusses the narrowing effect of digital inclusive finance on the wage income gap, property income gap and transfer income gap of urban and rural residents, as well as the regional heterogeneity characteristics of each and the insignificant impact on the net operating income gap between urban and rural operation from the perspective of income structure.

Third, this paper integrates the total amount of income and income structure, and use the mediating effect model to explore the negative influence mechanism of digital inclusive finance on the disposable income gap between urban and rural residents through the channel of income structure. In these four sub-items of income, we find that digital financial inclusion mainly narrows the overall income gap by narrowing the wage income gap.

Finally, we test robustness by replacing Theil - $\mathrm{L}$ index with Theil - $\mathrm{T}$ index, and discuss endogeneity by using two instrumental variables.

When it comes to research implications, this paper explores the impact of digital financial inclusion on the urban-rural income gap from the perspective of income structure. The sub-item income gaps are not completely similar with the total income gap, so future research may inspect income gaps with income structures. Additionally, as for society implications, Digital inclusive finance is conducive to alleviating poverty and promoting equity. Nowadays, China has done a good job in this realm, and the practical experience can also be extended to other areas.

However, two limitations of this article exist. First, there is room to expand the sample size. At present, we only select data at the provincial level. Therefore, we hope future research could dig deeper into municipal and county-level data. Second, there is room for improvement in instrumental variables. There are still problems in the instrumental variable of the ratio of the digital financial inclusion index and the distance between the 
provincial capitals of each sample province and Hangzhou, because it is equivalent to the component of endogenous variables.

Author Contributions: Conceptualization and editing N.Y., methodology and writing Y.W. All authors have read and agreed to the published version of the manuscript.

Funding: This work was conducted within the framework of the project: Research on rural financial development, implementation of inclusive finance and financial stability in Jilin Province (JJKH20190212SK) and financed by The Education Department of Jilin Province. The funder had no role in the study design, data collection and analysis, decision to publish, or preparation of the manuscript.

Institutional Review Board Statement: Not applicable.

Informed Consent Statement: Not applicable.

Data Availability Statement: The data presented in this study are openly available in the institute of Digital Finance of Peking University. https: / / en.idf.pku.edu.cn/achievements/seriesofdigitafinanceindexes / 490847.htm (accessed on 10 October 2020).

Conflicts of Interest: The authors declare no conflict of interest.

\section{References}

1. Waller, G.M. Microcredit and Third World Development Policy. Policy Stud. J. 2001, 29, 265-266. [CrossRef]

2. Satya, R.; Chakravarty, R.P. Financial inclusion in India: An axiomatic approach. J. Policy Modeling 2013, 35, 813-837.

3. Kodan, A.S.; Chhikara, K.S. A theoretical and quantitative analysis of financial inclusion and economic growth. Manag. Labour Stud. 2013, 38, 103-133.

4. Schmied, J.; Marr, A. Financial Inclusion And Poverty: The Case of Peru. Reg. Sect. Econ. Stud. 2016, 16, 29-40.

5. Song, X. Empirical Analysis of Digital Inclusive Finance Bridging the Urban-rural Residents' Income Gap. Sci. Financ. Econ. 2017, $6,14-25$.

6. Yanzhi, Z.Z.T. Digital financial inclusion and China's urban-rural income gap: An empirical analysis based on a spatial econometric Model. Financ. Theory Pract. 2018, 6, 1-7.

7. Zhang, H.; Bai, Q. Has digital financial inclusion narrowed the urban-rural income gap: Panel threshold regression analysis based on provincial data in China. Explor. Econ. Probl. 2018, 10, 122-129.

8. Peipei, L.S.L. Digital Inclusive Finance and the Income Gap Between Urban and Rural Areas. J. Cap. Univ. Econ. Bus. 2019, 1, 33-41.

9. Xiong, D.; Chen, Y. The Influence of Digital Inclusive Finance Development on the Urban-rural Income Gap: Empirical Analysis Based on Disequilibrium Effect and Threshold Effect. Chang. J. 2020, 5, 99-106.

10. Ca, A.C. Income inequality and the quality of imports. Rev. World Econ. 2021, 157, 375-416.

11. Sunde, R.K.U. Income Shocks, Inequality, and Democracy. Scand. J. Econ. 2021, 123, 295-326.

12. Yu, L.-r.; Li, X.-y. The effects of social security expenditure on reducing income inequality and rural poverty in China. J. Integr. Agric. 2021, 20, 1060-1067. [CrossRef]

13. Furusawa, T.; Konishi, H.; Duong, T.L.A. International Trade and Income Inequality. Scand. J. Econ. 2020, 3, 993-1026. [CrossRef]

14. Foltz, J.; Guo, Y.; Yao, Y. Lineage networks, urban migration and income inequality: Evidence from rural China. J. Comp. Econ. 2020, 48, 465-482. [CrossRef]

15. Jensen, B.C.; Butler, J.L.W.; Brown, D.L.; Jensen, L. Income Inequality across the Rural-Urban Continuum in the United States, 1970-2016. Rural Sociol. 2020, 85, 899-937.

16. Wen, Z. Study on the income gap between urban and rural residents in the Inner Mongolia Autonomous Region based on the source of income. Math. Pract. Theory 2017, 4, 52-61.

17. Zhong, D.; Xiao, Y. The impact of basic public service supply on urban-rural income gap: Based on the perspective of different income sources. J. Southwest Univ. Natl. 2020, 41, 105-114.

18. Yue, Z. Digital financial inclusion development and family entrepreneurship. J. Nanjing Univ. Posts Telecommun. 2021, 5, 1-16.

19. Li, J. Empirical study on the relationship between the development of digital inclusive finance and rural revitalization. Stat. Decis. Mak. 2021, 4, 1-5.

20. Shen, X. Research on Digital Inclusive Finance Boosting Rural Economic Development. Shanxi Agric. Econ. 2021, 7, 10-13.

21. Yong, H. Research on Digital Inclusive Finance Helping Small and Medium-sized Enterprises Development. Sme Manag. Technol. 2021, 4, 66-67.

22. Xiaoyi, R. Whether the development of digital inclusive finance can ease the financing constraints of enterprises. Discuss. Mod. Econ. 2020, 10, 65-75.

23. Chengying, N. Expand the channel research of our country farmer property income in new period. Agric. Econ. 2015, 3, 56-58. 
24. He, Y.; Wang, M.; Li, Y.; Li, J. Is the digitization of inclusive finance a "digital dividend"?- Based on the perspective of income growth of rural residents. South. Financ. 2020, 12, 71-84.

25. Yan, X. The "Dividend" and "Gap" of Rural Digital Inclusive Finance. Economist 2021, 2, 102-111.

26. Guo, F.; Wang, Y. Traditional financial foundation, knowledge threshold and digital finance to the countryside. Study Financ. Econ. 2020, 1, 19-33.

27. Liang, X. An Empirical Study on the Effects of Digital Financial Inclusion on Local Tax. Audit. Econ. Res. 2020, 5, 96-104.

28. Huang, Z.H.; Lu, J.Q.; Wang, M. The Study of the Rural-urban Income Inequality: A View from Residents' Income Resource. J. Zhejiang Univ. 2005, 4, 122-130.

29. Hao, L.; Zhang, Y.F.; Wang, Q. Let's talk about the statistical measurement of the Gini coefficient. Stat. Decis. Mak. $2021,7,37$.

30. $\mathrm{Hu}, \mathrm{Z}$. Study on the theoretical optimum value of Gini coefficient and its simple calculation formula. Econ. Res. 2004, 9, 60-69.

31. Liu, Y.; Xie, M.; Ding, Y. Comparison and reflection on the calculation methods of Gini coefficient. Stat. Decis. Mak. 2004, 9, 15-16.

32. Bingqi, Z. Digital financial inclusion and urban-rural income gap in China: An empirical study based on panel threshold Model. Soc. Sci. J. 2020, 1, 196-205.

33. Li, C.; Shang, Y.P. The Influential Factor Decomposition and Its Threshold Effect for Rural-urban Income Gap in China. West. Forum 2017, 5, 37-46.

34. Han, X.; Han, S. Analysis on the Change of the Income Gap of Chinese Residents: Based on the 1978-2003 Time Series Analysis. Res. Financ. Econ. Issues 2006, 10, 74-80.

35. Guo, F.; Wang, J.; Wang, F.; Kong, T.; Zhang, X.; Cheng, Z. Measuring China's Digital Financial Inclusion: Index Compilation and Spatial Characteristics. China Econ. Q. 2020, 19, 1401-1418.

36. Wang, H. Analysis of urban-rural income gap in China: Based on the decomposition of Theil index. Econ. Forum 2009, 12, 4-8.

37. Yuan, L. Theil index analysis of income inequality in China. J. Yunnan Univ. Financ. Econ. 2008, 1, 30-37.

38. Wang, E. Theil index measure of regional income disparity. Open Her. 2003, 1, 39-42.

39. $\mathrm{Wu}, \mathrm{X}$; $\mathrm{Liu}, \mathrm{Z}$. A study on the influencing factors of urban-rural income gap in China: Based on the analysis of provincial Panel Data during 2002-2011. Contemp. Econ. Sci. 2014, 36, 46-54, 125-126.

40. Wen, Z.; Zhang, L.; Hou, T.; Liu, H. Mediation effect test program and its application. J. Psychol. 2004, 5, 614-620.

41. Wen, Z.; Ye, B. Mediating effect analysis: Methodology and model development. Adv. Psychol. Sci. 2014, 22, 731-745. [CrossRef]

42. Fang, J.; Zhang, M.; Qiu, H. Testing methods for mediating effects and measurement of effect sizes: Review and prospect. Psychol. Dev. Educ. 2012, 28, 105-111.

43. Yan, J.; Feng, J. Research on the Impact of Digital Inclusive Finance on Residents' Consumption Upgrade. Consum. Econ. 2021, 37, 79-88.

44. Zhou, L.; Liao, J.; Zhang, H. Digital Financial Inclusion, Credit Availability and Resident Poverty Emission: Microscopic Evidence from the Chinese Household Survey. Econ. Sci. 2021, 1, 145-157.

45. Hu, B.; Cheng, X. Fintech, Digital Inclusive Finance and National Financial Competitiveness. J. Wuhan Univ. 2020, 73, $130-141$.

46. Zheng, M. Rural Digital Financial Inclusion: Development Models and Typical Cases. Agric. Econ. 2019, 3, 96-104.

47. Huo, Y. Opportunities and risks of digital financial inclusion. New Financ. 2017, 8, 4-7. 